\title{
Analisis Pengaruh Teknologi SRAN (Single Radio Access Network) Terhadap Modernisasi Arsitektur Jaringan Telekomunikasi
}

\author{
Julia Permata Sari'; Peby Wahyu Purnawan² \\ ${ }^{1,2}$ Program Studi Teknik Elektro, Universitas Budi Luhur Jakarta \\ ${ }^{2}$ pebywahyupurnawan@budiluhur.ac.id
}

\begin{abstract}
Idea Single Radio Access Network is simple operating different radio technologies on single multipurpose hardware platform. its most developed form, SRAN comprise one radio installation with common transport, operational and management system integrated unified security across Radio Access Technologies. In addition, it enables coordination and operation of different RATs in a unified way, able to use existing RATs to bring best performance by coordinating their advantages. Modularity is a key enabler, allowing capacity to be scaled up in line with demand, new and existing spectrum to be used more efficiently. North Sumatra-DRDTOBINJAI2 site area that has been chosen to be modernized by SRAN solution. Result of implementation has been tested and analyzed, SRAN is simplify hardware usage from 5 system and 5 transport module become 3 system and 2 tranport module with additional LTE 900 and 2100 upgrades in this site. Operational efficiency improved through network sharing, energy efficiency of the radio network raised $27 \%$ and software can be used to define functions of the hardware for ultimate flexibility, performance and cost effectiveness. By doing the drive test, SRAN improve the throughput of uplink rate up to 10 Mbps and reduce delay time from $>70 \mathrm{~ms}$ to $40 \mathrm{~ms}$.
\end{abstract}

Keywords: SRAN, RAT, modernized, network sharing, energy efficiency

\begin{abstract}
ABSTRAK
Gagasan Single Radio Access Network sangat sederhana yaitu dapat mengoperasikan berbagai teknologi radio pada satu platform hardware multiguna. Dalam pengembangan terbaru, SRAN terdiri dari satu instalasi radio dengan common transport dan sistem operasional dan manajemen dengan keamanan terpadu di seluruh RATs (Radio Access Technologies). Selain itu, SRAN dapat mengkoordinasikan dan mengoperasikan berbagai RAT secara terpadu serta mampu menggunakan RAT yang ada untuk menghasilkan kinerja terbaik dengan mengoordinasikan keuntungan masingmasing RAT. Modularitas adalah enabler utama yang meningkatkan kapasitas sesuai dengan permintaan dan spektrum baru dan spektrum yang ada dapat digunakan lebih efisien. Sumatra Utara - site DRDTOBINJAI2 adalah lokasi yang dipilih untuk dimodernisasi dengan solusi SRAN. Hasil implementasi pada site tersebut setelah diuji dan dianalisa, SRAN dapat menyederhanakan penggunaan hardware dari 5 modul sistem dan 5 modul transmisi menjadi 3 modul sistem dan 2 modul transmisi dengan menambahkan teknologi LTE band 900 dan 2100 pada site tersebut. Efisiensi pada operasional meningkat melalui network sharing, efisiensi energi jaringan radio meningkat $27 \%$ dan software dapat digunakan untuk menentukan fungsi hardware agar lebih fleksibel, performa lebih baik dan meningkatkan efektifitas biaya. Dengan melakukan drive test, SRAN terbukti meningkatkan throughput pada uplink hingga 10 Mbps dan mengurangi waktu delay dari >70 ms menjadi $40 \mathrm{~ms}$.
\end{abstract}

Kata kunci: SRAN, RAT, modernisasi, network sharing, efisiensi energi 


\section{PENDAHULUAN}

Pengembangan LTE telah memainkan peran kunci dalam era IoT (Internet of Things) di dunia pada umumnya dan di Indonesia khususnya. Namun tidak sedikit permasalahan yang dialami oleh operator setelah jaringan 4G. Ketidakpastian capacity life cycle, ledakan traffic yang mempengaruhi kualitas jaringan dan perangkat baru RAN (Radio Access Network) yang menambah kompleksitas dan biaya serta pertumbuhan biaya energi menjadi kunci utama yang mendorong operator untuk mencari solusi terbaik untuk mengatasi permasalahan tersebut.

Dalam beberapa penelitian, ada beragam solusi yang ditawarkan diantaranya seperti Air Scale Solution yang mengganti perangkat base station dan antena dengan menggunakan solar cell dan tenaga angin sebagai energi utama, air scale mengusung tema "zero emissions" sebagai highlight pada solusinya. Dengan Air Scale, peak data rates dapat mencapai 1 Gbps, pengalaman gigabit adalah peluang pendapatan utama bagi operator [1]. Namun, solusi ini terbentur dengan investasi awal yang cukup besar bagi operator. Berikutnya, SRAN (Single Radio Access Network) Solution dengan menggunakan perangkat baseband Flexi Multiradio 10 BTS sebagai modul sistem [2] atau menggunakan single board UBBPd6 card dan rectangular antenna [3]. SRAN dapat membuat kompleksitas yang ada dalam arsitektur jaringan menjadi lebih sederhana pada sisi base station karena dapat mendukung berbagai teknologi RF dalam satu jaringan. Selanjutnya, Cloud RAN Solution, platform RAN konvensional didasarkan pada kepemilikan hardware dan bergantung pada long life cycles dalam pengembangan, penyebaran, dan pengoperasian. Cloud RAN memungkinkan pemisahan beberapa atau semua fungsi baseband dari remote radio unit yang dijalankan sebagai VNF (Virtualized Network Function) pada komoditas hardware, memungkinkan kemampuan centralized, seperti CoMP (Coordinated Multi Point), schedulling dan manajemen interferensi, tanpa perlu bertukar informasi di antara banyak node akses [4][5].

Diantara semua solusi di atas, SRAN Solution dengan menggunakan perangkat baseband Flexi Multiradio 10 BTS sebagai system module dapat membuat kompleksitas yang ada dalam arsitektur jaringan menjadi lebih sederhana pada sisi base station karena dapat mendukung berbagai teknologi RF dalam satu jaringan. Teknologi SRAN dengan Flexi Multiradio 10 BTS mempunyai keunggulan karena dinilai paling efisien dalam segi hardware, operasional dan manajemen serta pengeluaran OPEX (Operating Expenses). Dari segi hardware, kompatibilitas existing modul RF di site akan diuji sehingga operator dapat tetap menggunakan RF module existing yang mendukung implementasi SRAN. Pada operasi dan manajemen, semua network element dikelola hanya dengan 1 IP address, host dan interface serta security yang membuat monitoring network menjadi semakin mudah dan cepat. Sedangkan dari sisi OPEX akan lebih hemat karena dengan teknologi SRAN energi yang dikonsumsi base station menjadi lebih efisien.

\section{METODE / PERANCANGAN PENELITIAN}

Metode penelitian yang digunakan dalam penelitian adalah metode kuantitatif. Data diperoleh langsung dari site yang diobservasi seperti pengumpulan parameter awal dari site existing meliputi BSC configuration, traffic data, packet loss ratio, delay, throughput dan hardware yang digunakan.

\subsection{Spesifikasi Dan Parameter Site Existing}

Spesifikasi dan parameter site existing dibutuhkan untuk mengetahui keadaan awal jaringan. Site DRDTOBINJAI2 terletak di area urban dengan coverage makro. Band yang tersedia pada site tersebut adalah 900/1800/2100 (GSM/DCS-LTE/3G). Data konfigurasi modul pada site DRDTOBINJAI2 yang diambil pada tanggal 15 Januari 2019 adalah sebagai berikut. 
Tabel 1. Konfigurasi Site DRDTOBINJAI2

\begin{tabular}{|l|l|l|}
\hline $\begin{array}{l}\text { Jenis } \\
\text { Modul }\end{array}$ & Teknologi & $\begin{array}{l}\text { Jumlah_Tipe } \\
\text { Modul }\end{array}$ \\
\hline \multirow{5}{*}{ SMOD } & G900 & 1_FSMF \\
\cline { 2 - 3 } & U900 & 1_FSMF \\
\cline { 2 - 3 } & D1800 & 1_FSMF \\
\cline { 2 - 3 } & L1800 & 1_FSMF \\
\cline { 2 - 3 } & U2100 & 1_FSMF \\
\hline \multirow{5}{*}{ RMOD } & G900 & share_U900 \\
\cline { 2 - 3 } & U900 & 1_FXDA \\
\cline { 2 - 3 } & D1800 & share L1800 \\
\cline { 2 - 3 } & L1800 & 1_FXED \\
\cline { 2 - 3 } & U2100 & 1_FRGT \\
\hline \multirow{5}{*}{ TMOD } & G900 & 1_FTIF \\
\cline { 2 - 3 } & U900 & 1_FTIF \\
\cline { 2 - 3 } & D1800 & 1_FTIF \\
\cline { 2 - 3 } & L1800 & 1_FTIF \\
\cline { 2 - 3 } & U2100 & 1_FTIF \\
\hline
\end{tabular}

Pada tabel 1 dapat dilihat bahwa modul sistem existing sudah menggunakan FSMF yang mendukung SRAN. Setiap teknologi harus memiliki masing-masing modul inti untuk modul sistem dan transmisi. Sedangkan RF modul sudah kompatibel dengan RF sharing. Dengan RF sharing penggunaan modul RF dapat dipakai berbagai teknologi tergantung dengan spesifikasi dari modul RF tersebut.

\subsection{Parameter QoS (Quality of Service)}

Pada penelitian ini ada 3 parameter yang digunakan untuk pengambilan data, yaitu:

\section{$>$ Packet Loss}

Packet loss dapat disebabkan oleh sejumlah faktor, mencakup penurunan signal dalam media jaringan, melebihi batas saturasi jaringan, paket yang corrupt yang menolak untuk transit dan kesalahan perangkat keras jaringan. Packet loss ratio pada jaringan existing seperti yang terlihat pada gambar 1 .

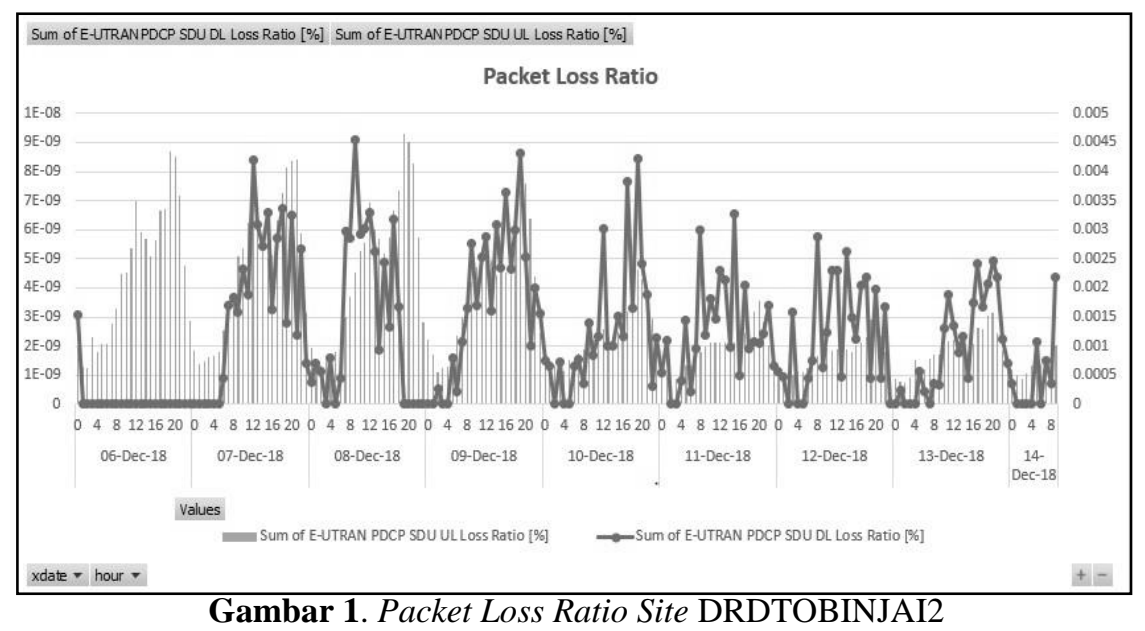

Video adalah traffic yang sangat sulit bagi jaringan, sehingga packet loss dapat disadari oleh user jika mencapai $0,5 \%$ dan akan sangat mengganggu jika lebih dari $2 \%$. Bahkan jika 
packet loss lebih besar dari 2\% dapat menyebabkan panggilan gagal. Packet loss ratio untuk L1800 site DRDTOBINJAI2 masih tergolong baik karena kurang dari 0,5\%. Meskipun begitu, mengurangi packet loss adalah hal yang terus menjadi perhatian bagi provider.

\section{Delay (Latency)}

Delay diperoleh dari selisih waktu kirim antara satu paket TCP dengan paket lainnya.

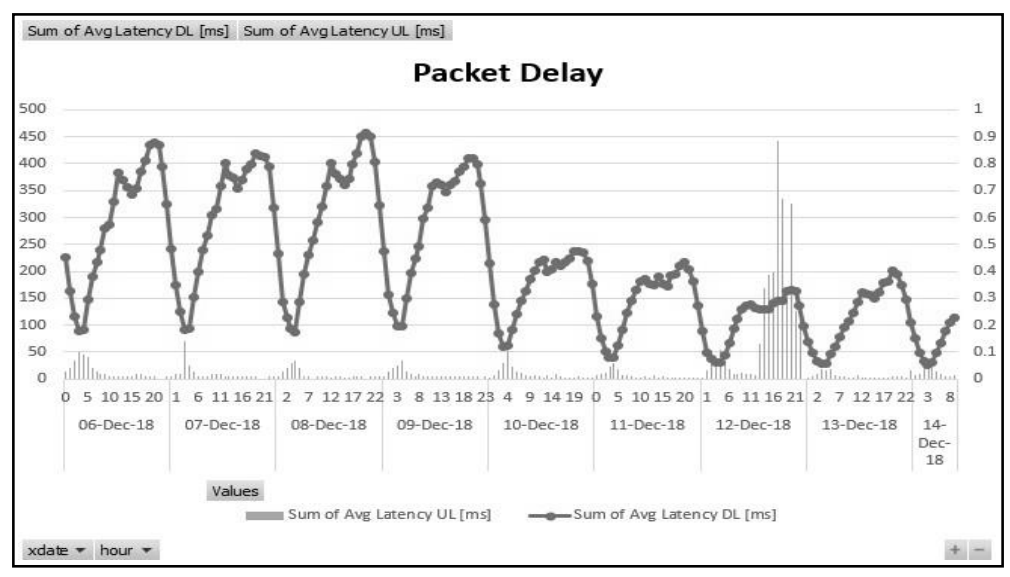

Gambar 2. Packet Delay Site DRDTOBINJAI2

Pada gambar 2 terlihat grafik trend delay atau latency semakin lama semakin menurun. Latency dibawah $100 \mathrm{~ms}$ masih dapat ditolerir. Tetapi besarnya delay yang terjadi pada jaringan sangat mengganggu karena sudah lebih dari 150ms. Untuk orang yang sedang bermain game, latency harus kurang dari 50ms dan idealnya kurang dari 30ms. Hal ini terjadi karena transmisi di site DRDTOBINJAI2 masih menggunakan PDH (Plesynchronous Digital Hierarcy) dimana kecepatan link transmisi PDH masih sangat kurang untuk digunakan dalam transmisi data dalam hal ini teknologi LTE (4G).

\section{Throughput}

Throughput merupakan jumlah total kedatangan paket yang sukses yang diamati pada tujuan selama interval waktu tertentu dibagi oleh durasi interval waktu tersebut.

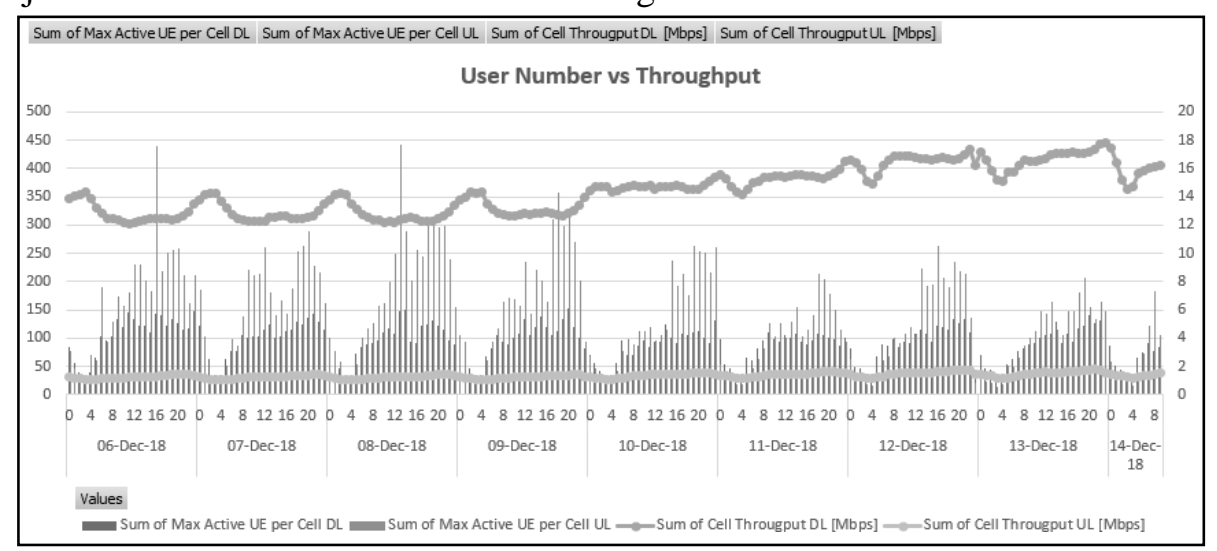

Gambar 3. UE (User Equipment) vs Throughput Site DRDTOBINJAI2

Pada gambar 3 terlihat trend throughput site DRDTOBINJAI2 masih dalam keadaan dapat diterima. Downlink rata-rata sebesar 13 Mbps, namun uplink masih tergolong rendah yaitu 


\section{Energi dan Kelistrikan: Jurnal Ilmiah}

Vol. 12, No. 1, Januari - Juni 2020, P-ISSN 1979-0783, E-ISSN 2655-5042

https://doi.org/10.33322/energi.v12i1.945

1,5 Mbps dengan traffic uplink yang sangat tinggi. Karena itu modernisasi SRAN difokuskan untuk membenahi kecepatan data baik downlink maupun uplink.

\subsection{Konsumsi Daya Modul BTS (Existing Site)}

Untuk mengetahui daya yang dikonsumsi BTS existing, pertama-tama yang harus dilakukan adalah mengumpulkan data konsumsi daya maksimum setiap modul yang digunakan pada BTS tersebut. Data konsumsi daya didapat dari data spesifikasi masing-masing modul dengan Total daya yang dikonsumsi oleh modul sistem dan RF sejumlah 3154 Watt [6][7]. Perhitungan konsumsi daya baik pada modul sistem maupun RF diambil nilai maksimum karena pada saat perangkat dinyalakan, perangkat mengkonsumsi daya maksimum. Walaupun ketika traffic sudah berjalan daya yang dikonsumsi adalah konsumsi daya tipikal.

\subsection{Perencanaan Upgrade}

Setelah mengetahui dan mengklasifikasikan permasalahan pada site tersebut, langkah yang dilakukan adalah memodernisasi teknologi di site tersebut dengan menggunakan teknologi SRAN. Selain itu, solusi yang dilakukan yaitu menambahkan teknologi LTE untuk band 900 dan 2100. Berdasarkan design planning, beberapa hardware harus ditambahkan untuk mendukung modernisasi SRAN dan penambahan teknologi tersebut adalah modul capacity extension dan RF.

Pada konfigurasi site existing modul sistem yang digunakan untuk modernisasi SRAN adalah Flexi Multi Radio 10 (FMR 10). FMR 10 memiliki 7 tipe modul, sedangkan pada site DRDTOBINJAI2 menggunakan 4 modul yaitu modul sistem existing FSMF (outdoor) yang dikombinasikan dengan sub- modul existing capacity extension FBBA dan sub-modul tambahan FBBC serta existing modul transmisi FTIF. Modul existing yang diperlukan antara lain modul sistem hanya 3 perangkat dan modul transmisi hanya 2 perangkat, sisanya di dismantle dari site. Sedangkan RF modul existing FXED tetap digunakan untuk mendukung band L1800. RF modul tambahan yang digunakan adalah FRGU untuk mendukung band L2100 dan FXDB untuk mendukung band L900. Semua modul tersebut diuji dalam testbed untuk mengecek kompatibilitas terhadap software SRAN.

\subsection{Kebutuhan Software}

Dalam penelitian ini software yang digunakan untuk mendukung observasi keadaan jaringan awal maupun pengujian setelah modernisasi teknologi SRAN adalah sebagai berikut:

\section{$>$ BTS WebEM (Web Element Manager)}

BTS WebEM adalah software shareware yang dikembangkan oleh Nokia dan digunakan untuk mengoperasikan BTS. WebEM menggantikan aplikasi yang sebelumnya digunakan yaitu BTS Site Manager. WebEM dapat digunakan on site maupun remote karena aplikasi tersebut berbasis standar web browser (chrome prefer). Keunggulan dari WebEM ini adalah tidak perlu meng-install aplikasi pada sisi client. Dalam penelitian ini, aplikasi ini digunakan untuk monitoring BTS/network secara remote.

\section{$>$ G-NetTrack}

G-NetTrack adalah aplikasi netmonitor dan drive test untuk jaringan radio 5G/4G/3G/2G (NR/LTE/UMTS/GSM/CDMA/EVDO). Aplikasi ini dapat membantu memantau layanan mobile network dan neighbor cell tanpa menggunakan peralatan khusus. Tetapi tidak bisa mendapatkan throughput pengetesan secara real time. 


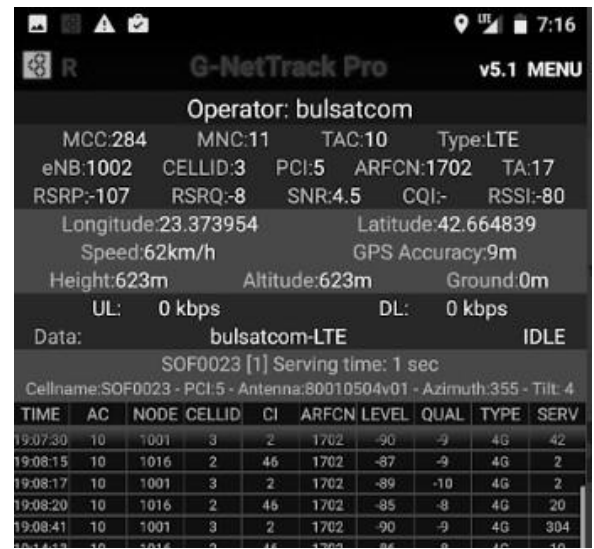

Gambar 4. Aplikasi G-NetTrack Pro

\section{Speedtest by Ookla}

Aplikasi ini berfungsi untuk menguji kecepatan dan kinerja koneksi internet secara real time.

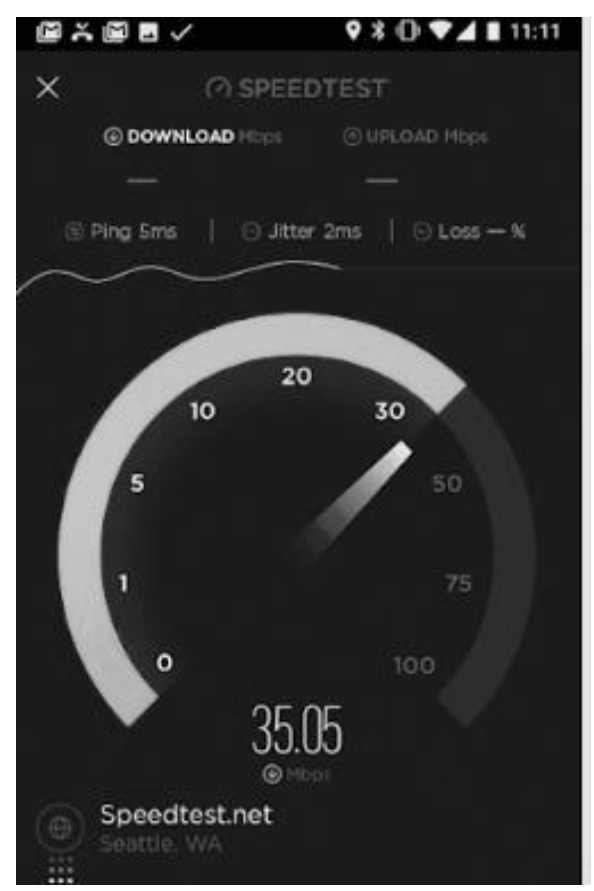

Gambar 5. Aplikasi Speedtest by Ookla

Dengan menggunakan aplikasi ini, dapat mengetahui berapa besar kecepatan download dan upload dari provider yang digunakan secara real time di area pengujian.

\section{HASIL DAN PEMBAHASAN}

\subsection{Testbed}

Testbed merupakan istilah pengujian terhadap alat atau teknologi baru. Dalam penelitian ini, testbed dilakukan pada RF modul FRGU sebelum dipasang di site DRDTOBINJAI2. Hasil testbed seperti terlihat pada gambar 6 . 


\section{Energi dan Kelistrikan: Jurnal Ilmiah}

Vol. 12, No. 1, Januari - Juni 2020, P-ISSN 1979-0783, E-ISSN 2655-5042

https://doi.org/10.33322/energi.v12i1.945

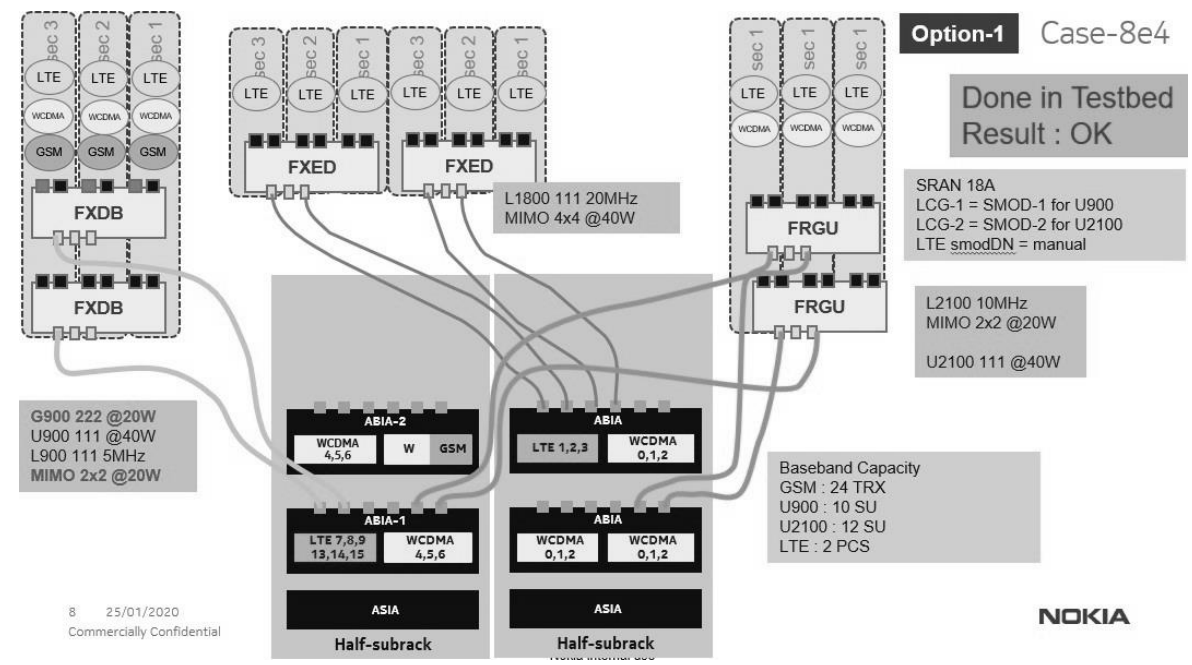

Gambar 6. Hasil Testbed RF Modul FXED-FXDB-FRGU

Setelah dilakukan testbed terhadap ketiga modul RF (FXED, FXDB dan FRGU), didapatkan kapasitas baseband maksimum sebagai berikut:

1. GSM: 24 TRX

2. U900: 10 Sub Unit

3. U2100: 12 Sub Unit

4. LTE: 2 PCS

Kapasitas baseband ini berkurang jika dibandingkan dengan teknologi sebelumnya. Hal ini dikarenakan teknologi SRAN menggunakan modul sistem yang sama untuk semua band sehingga kapasitas terbagi.

\subsection{Drive Test}

Drive test dilakukan untuk mengetahui performansi jaringan yang sudah dimodernisasi ke SRAN. Parameter yang diukur salah satunya adalah throughput. Drive test dilakukan sebanyak 2 kali karena ada 2 tahapan modernisasi. Berdasarkan hasil drive test yang disajikan setelah pengolahan data menggunakan G-NetTrack dan Speedtest by Ookla, throughput yang didapatkan adalah sebagai berikut sesuai pada Gambar.7 Capture hasil drive test add L2100:

\begin{tabular}{|c|c|c|c|c|c|c|c|}
\hline \multirow{2}{*}{$\begin{array}{c}\text { No. } \\
3\end{array}$} & \multirow[t]{2}{*}{ Item Test } & \multirow[t]{2}{*}{ Sector\# } & \multirow{2}{*}{$\begin{array}{l}\text { MIMo } \\
\text { Enable }\end{array}$} & \multicolumn{2}{|c|}{ Target Value } & \multirow{2}{*}{$\begin{array}{c}\text { Achieve } \\
\text { Value }\end{array}$} & \multirow{2}{*}{$\begin{array}{l}\text { VideoCapture |FramePosition } \\
\text { (mm.ss.msmsms-mm.ss.msmsms) }\end{array}$} \\
\hline & & & & $\begin{array}{c}\text { MIMO 2X2 } \\
\text { (Current Treshold) }\end{array}$ & $\begin{array}{c}\text { MIMO 2X2 } \\
\text { (New Treshold) }\end{array}$ & & \\
\hline & 3.1. Throughput Downlink & 1 & MIMO 2X2 & $>=15 \mathrm{Mbps}$ & $>=3,5 \mathrm{Mbps}$ & $6.1 \mathrm{Mbps}$ & \multirow{3}{*}{ 00:01:19.000-00:01:23.000 } \\
\hline & 3.2. Throughput Uplink & 1 & MIMO 2X2 & $>=4 \mathrm{Mbps}$ & $>=1 \mathrm{Mbps}$ & $10 \mathrm{Mbps}$ & \\
\hline & 3.3. Latency & 1 & MIMO 2X2 & \multicolumn{2}{|c|}{$<70 \mathrm{~ms}$ (Capture Only) } & $40 \mathrm{~ms}$ & \\
\hline & & & & & & & \multirow{4}{*}{ 00:01:19.000-00:01:23.000 } \\
\hline & & 2 & IVIIVIU Zaล & $>=15 \mathrm{Mbps}$ & $>=3,5 \mathrm{Mbps}$ & $8.6 \mathrm{Mbps}$ & \\
\hline & 3.5. Throughput Uplink & 2 & MIMO 2X2 & $>=4 \mathrm{Mbps}$ & $>=1 \mathrm{Mbps}$ & $10 \mathrm{Mbps}$ & \\
\hline & 3.6. Latency & 2 & MIMO 2X2 & \multicolumn{2}{|c|}{$<70$ ms (Capture Only) } & $42 \mathrm{~ms}$ & \\
\hline & 3.7. Throughput Downlink & 3 & MIMO 2X2 & $>=15 \mathrm{Mbps}$ & $>=3,5 \mathrm{Mbps}$ & $7.1 \mathrm{Mbps}$ & \multirow{3}{*}{ 00:01:19.000-00:01:23.000 } \\
\hline & 3.8. Throughput Uplink & 3 & MIMO 2X2 & $>=4 \mathrm{Mbps}$ & $>=1 \mathrm{Mbps}$ & $9.4 \mathrm{Mbps}$ & \\
\hline & 3.9. Latency & 3 & MIMO 2X2 & \multicolumn{2}{|c|}{$<70 \mathrm{~ms}$ (Capture Only) } & $41 \mathrm{~ms}$ & \\
\hline
\end{tabular}

Gambar 7. Capture Hasil Drive Test Add L2100 
Energi dan Kelistrikan: Jurnal Ilmiah

Vol. 12, No. 1, Januari - Juni 2020, P-ISSN 1979-0783, E-ISSN 2655-5042 https://doi.org/10.33322/energi.v12i1.945

\begin{tabular}{|c|c|c|c|c|c|c|c|}
\hline \multirow{2}{*}{$\begin{array}{c}\text { No. } \\
3\end{array}$} & \multirow[t]{2}{*}{ Item Test } & \multirow[t]{2}{*}{ Sector\# } & \multirow{2}{*}{$\begin{array}{l}\text { MIMo } \\
\text { Enable }\end{array}$} & \multicolumn{2}{|c|}{ Target Value } & \multirow{2}{*}{$\begin{array}{l}\text { Achieve } \\
\text { Value }\end{array}$} & \multirow{2}{*}{$\begin{array}{c}\text { VideoCapture |FramePosition } \\
\text { (mm.ss.msmsms-mm.ss.msmsms) }\end{array}$} \\
\hline & & & & $\begin{array}{c}\text { MIMO 2X2 } \\
\text { (Current Treshold) }\end{array}$ & $\begin{array}{c}\text { MIMO 2X2 } \\
\text { (New Treshold) }\end{array}$ & & \\
\hline & 3.1. Throughput Downlink & 1 & MIMO 2X2 & $>=15 \mathrm{Mbps}$ & $>=3.5 \mathrm{Mbps}$ & $9.4 \mathrm{Mbps}$ & \multirow{3}{*}{ 00:01:19.000-00:01:23.000 } \\
\hline & 3.2. Throughput Uplink & 1 & MIMO $2 \times 2$ & $>=4 \mathrm{Mbps}$ & $>=1 \mathrm{Mbps}$ & $6.7 \mathrm{Mbps}$ & \\
\hline & 3.3. Latency & 1 & MIMO 2X2 & \multicolumn{2}{|c|}{$<70 \mathrm{~ms}$ (Capture Only) } & $41 \mathrm{~ms}$ & \\
\hline & 3.4. Throughput Downlink & 2 & MIMO $2 \times 2$ & $>=15 \mathrm{Mbps}$ & $>=3.5 \mathrm{Mbps}$ & $4.5 \mathrm{Mbps}$ & \multirow{3}{*}{ 00:01:19.000-00:01:23.000 } \\
\hline & 3.5. Throughput Uplink & 2 & MIMO 2X2 & $>=4 \mathrm{Mbps}$ & $>=1 \mathrm{Mbps}$ & 3.3 Mbps & \\
\hline & 3.6. Latency & 2 & MIMO $2 \times 2$ & \multicolumn{2}{|c|}{$<70 \mathrm{~ms}$ (Capture Only) } & $44 \mathrm{~ms}$ & \\
\hline & 3.7. Throughput Downlink & 3 & MIMO 2X2 & $>=15 \mathrm{Mbps}$ & $>=3.5 \mathrm{Mbps}$ & $12 \mathrm{Mbps}$ & \multirow{3}{*}{ 00:01:19.000-00:01:23.000 } \\
\hline & 3.8. Throughput Uplink & 3 & MIMO 2X2 & $>=4 \mathrm{Mbps}$ & $>=1 \mathrm{Mbps}$ & $6.6 \mathrm{Mbps}$ & \\
\hline & 3.9. Latency & 3 & MIMO 2X2 & \multicolumn{2}{|c|}{$<70 \mathrm{~ms}$ (Capture Only) } & $44 \mathrm{~ms}$ & \\
\hline
\end{tabular}

Gambar 8. Capture Hasil Drive Test New L900 5MHz

Target threshold yang diinginkan dengan teknologi MIMO 2x2 yaitu upload dengan batas atas 3.5 Mbps dan batas bawah 1.5 Mbps. Sedangkan untuk download, batas atas 15 Mbps dan batas bawah 4 Mbps. Pada pengujian (drive test), nilai throughput yang tercapai pada masing-masing sektor terlihat pada gambar 7 untuk LTE 2100 dan gambar 8 untuk LTE 900 5MHz. Nilai yang didapatkan masih memenuhi range target. Parameter lain seperti network latency tidak boleh lebih dari $70 \mathrm{~ms}$. Namun jika dibandingkan dengan hasil drive test sebelum dilakukan upgrade, throughput tidak begitu jauh berbeda.

\subsection{Efisiensi Daya}

Untuk menghitung efisiensi daya, yang dilakukan pertama kali adalah mengambil data konfigurasi site untuk mengetahui hardware apa saja yang terpasang setelah dimodernisasi. Data site konfigurasi DRDTOBINJAI2 diambil pada tanggal 12 Januari 2020. Dilihat dari data konfigurasi site setelah modernisasi ke SRAN, terdapat penambahan teknologi L900 dan L2100 pada site DRDTOBINJAI2. Hal ini mempengaruhi penggantian dan penambahan modul seperti modul sistem dan RF, karena dengan software SRAN modul sistem dapat digunakan untuk beberapa network element.

Terlihat bahwa pada arsitektur SRAT, setiap teknologi harus didukung dengan 1 modul sistem dan 1 modul transport. Jumlah modul sistem yang dipakai tergantung dari berapa banyak teknologi yang ada pada site tersebut. Seperti kasus SRAT di site DRDTOBINJAI2, sebelumnya memiliki 5 teknologi yang aktif pada BTS tersebut sehingga membutuhkan 5 modul sistem dan 5 modul transport. Sedangkan setelah modernisasi ke SRAN, dengan menambah 2 teknologi baru, jumlah modul sistem bahkan berkurang dari 5 menjadi 3 FSMF dan modul transport berkurang dari 5 menjadi 2 FTIF. Hal ini berarti SRAN memungkinkan 1 modul sistem untuk mendukung 1 band frekuensi dimana didalamnya terdapat beberapa teknologi. Daya yang digunakan untuk perangkat modernisasi SRAN total berjumlah 4938 Watt.

Total daya setelah modernisasi lebih besar dibandingkan dengan arsitektur sebelumnya. Walaupun sistem modul sudah disimplifikasi dengan software SRAN tetapi ada penambahan perangkat untuk teknologi tambahan LTE 900 dan LTE 2100. Karena itu dilakukan simulasi perhitungan efisiensi daya dengan menggunakan konfigurasi site awal yang sudah dimodernisasi ke SRAN dengan membandingkan konsumsi daya dengan konfigurasi site yang sama maka didapatkan efisiensi daya sebesar $27,12 \%$. 


\section{Energi dan Kelistrikan: Jurnal Ilmiah}

Vol. 12, No. 1, Januari - Juni 2020, P-ISSN 1979-0783, E-ISSN 2655-5042

https://doi.org/10.33322/energi.v12i1.945

\subsection{Benefit Penggunaan SRAN (Single Radio Access Network)}

Setelah menganalisa hasil modernisasi arsitektur jaringan SRAN, manfaat yang dirasakan oleh operator, end user dan vendor adalah sebagai berikut :

\section{Operator}

- Manajemen operasi menjadi semakin mobile, mudah dan cepat.

- Mengurangi kompleksitas hardware pada BTS saat implementasi di lapangan dari 5 modul sistem dan 5 modul transmisi menjadi 3 modul sistem dan 2 modul transmisi.

- Mengurangi konsumsi daya modul secara keseluruhan sebesar $27 \%$, hal ini sangat berpengaruh terhadap pengurangan operating cost.

- Menambah kapasitas user dalam penggunaan data seperti terlihat pada gambar 9.

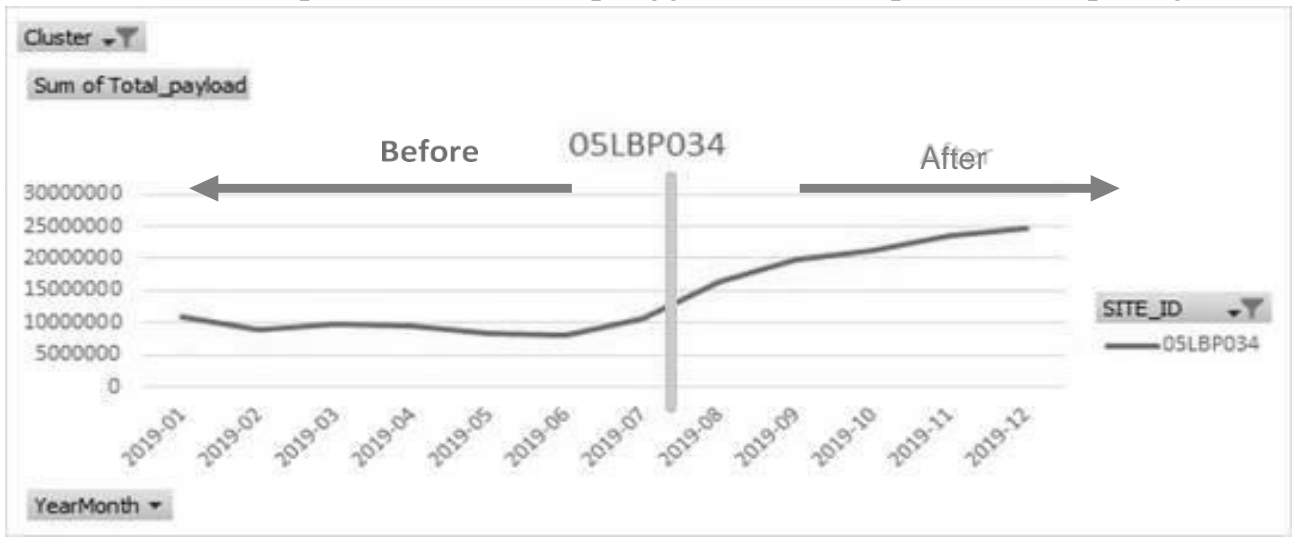

Gambar 9. Traffic Data Trend Site DRDTOBINJAI2

\section{End User}

- Kecepatan upload meningkat dari 1,5 Mbps menjadi 3,3 hingga 10 Mbps.

- Delay dalam mengunduh data semakin berkurang dari yang sebelumnya mencapai 150 ms menjadi $40 \mathrm{~ms}$.

\section{$>$ Vendor}

Monitoring network dan troubleshoot semakin mudah dan cepat.

\section{KESIMPULAN DAN SARAN}

Modernisasi yang sudah dilakukan pada site DRDTOBINJAI2, network sharing merubah konfigurasi modul dari 5 modul sistem dan 5 modul transmisi, menjadi 3 modul sistem dan 2 modul transmisi dengan sudah menambahkan teknologi LTE pada band 900 dan 2100. QoS Throughput yang dihasilkan setelah implementasi SRAN di lapangan dari sisi downlink tidak jauh berbeda dengan arsitektur sebelumnya namun ada peningkatan dari sisi uplink hingga mencapai $10 \mathrm{Mbps}$, kemudian Latency pada saat menggunakan arsitektur SRAT mencapai lebih dari $70 \mathrm{~ms}$, setelah implementasi SRAN jauh membaik menjadi $40 \mathrm{~ms}$ serta didapatkan hasil simulasi konfigurasi site awal menggunakan arsitektur SRAN efisiensi energi sebesar 27,12\%.

\section{UCAPAN TERIMAKASIH}

Penulis mengucapkan terima kasih kepada para Dosen khususnya dosen Pembimbing serta para teman-teman Prodi Elektro Universitas Budi Luhur yang telah memberi dukungan serta membantu pelaksanaan penelitian dan atau penulisan artikel ini. 


\section{DAFTAR PUSTAKA}

[1] Nokia, "You can' $t$ see the future, but you can be ready for it," 2017.

[2] NSN, "Single RAN Advanced Evolution: The future just got simpler," 2013.

[3] S. Sumathi and B. Uma, "Base-Band Processing Technology Supporting All Mobile Users," Int. J. Electron. Commun. Eng. Technol., vol. 8, no. 1, pp. 43-51, 2017.

[4] Mavenir, "Transforming the Radio Access Network Solution Description: Mavenir Cloud RAN," 2017.

[5] X. Wang et al., "Energy-Efficient Virtual Base Station Formation in Optical-Access-Enabled Cloud-RAN," IEEE J. Sel. Areas Commun., vol. 34, no. 5, pp. 1130-1139, 2016.

[6] N. Networks, "Flexi Multiradio BTS RF Module and Remote Radio Head Description," 2016.

[7] N. Networks, "LTE Radio Access, Rel . RL70, Operating Documentation, Issue 01 Flexi Multiradio 10 Base Station System Module Description," 2015. 